\title{
Pengaruh Model Pembelajaran Talking Chip Terhadap Kemampuan Komunikasi Matematis
}

\author{
Vera Wahyuni' ${ }^{1}$, \\ IAIN Syaikh Abdurrahman Siddiq Bangka Belitung
}

\begin{tabular}{l}
\hline \hline Info Artikel : \\
\hline Diterima 25 Januari, 2022 \\
Direvisi 27 Januari, 2022 \\
Dipublikasikan 31 Januari 2022
\end{tabular}

Kata Kunci: (Model
Pembelajaran, Talking Chips,
Komunikasi Matematis)

Keyword; ( Learning Model, Talking Chips, Mathematical Communication)

\begin{abstract}
ABSTRAK
Penelitian ini dilatar belakangi rendahnya kemampuan komunikasi matematis peserta didik. Hal ini dapat disebabkan oleh beberapa faktor diantaranya adalah kebanyakan guru matematika hanya menekankan pada materi semata dan lebih banyak menjalin komunikasi satu arah dengan peserta didik (teacher center) sehingga peserta didik kurang aktif dalam menyampaikan ide-idenya, mengingat bahwa pentingnya kemampuan komunikasi matematis maka perlu dikembangkan model pembelajaran yang erat hubunganya dengan kemampuan komunikasi matematis. Model tersebut diantaranya adalah model pembelajaran tipe Talking Chips bertujuan untuk mengetahui Pengaruh Model Pembelajaran Kooperatif Tipe Talking Chips terhadap Kemampuan Komunikasi Matematis Peserta Didik Kelas VIII SMP PGRI 1 Batanghari.

Jenis Penelitian ini adalah penelitian eksperimen dengan tiga kelompok sampel yaitu satu kelompok eksperimen dan satu kelompok kontrol. Kelompok eksperimen yang pertama memperoleh perlakuan dengan menggunakan model pembelajaran kooperatif tipe Talking Chips, sedangkan untuk kelompok kontrol mendapat perlakuan dengan pembelajaran konvensional yaitu ceramah. Untuk memberoleh data hasil penelitian digunakan instrumen berupa tes kemampuan komunikasi matematis, dokumentasi dan pedoman wawancara. Subyek penelitian adalah peserta didik kelas VIII SMP PGRI 1 Batanghari

Berdasarkan analisis variansi satu jalan terdapat Pengaruh Model Pembelanjaran Talking Chips Terhadap Kemampuan Komunikasi Matematis Peserta Didik Kelas VIII PGRI 1 Batanghari. Terdapat pengaruh yang signifikan model pembelajaran Talking Chips terhadap kemampuan komunikasi matematis dibandingkan dengan menggunakan Konvensional.
\end{abstract}

\section{ABSTRACT}

This research is motivated by the low mathematical communication skills of students. This can be caused by several factors including most mathematics teachers only emphasizing the material and more in one-way communication with students (teacher center) so that students are less active in conveying their ideas, given that the importance of mathematical communication skills is necessary. developed a learning model that is closely related to mathematical communication skills. These models include the Talking Chips type learning model, which aims to determine the effect of the Talking Chips Cooperative Learning Model on the Mathematical Communication Ability of Class VIII SMP PGRI 1 Batanghari Students.

This type of research is an experimental study with three sample groups, namely one experimental group and one control group. The first experimental group received treatment using the Talking Chips type cooperative learning model, while the control group received treatment with conventional learning, namely lectures. To obtain data from research results used instruments in the form of mathematical communication skills tests, documentation and interview guidelines. The research subjects were students of class VIII SMP PGRI 1 Batanghari

Based on one-way analysis of variance, the influence of the Talking Chips Expenditure Model on the Mathematical Communication Ability of Class VIII PGRI 1 Batanghari Students. There is a significant effect of the Talking Chips learning model on mathematical communication skills compared to conventional use.

This is an open access article distributed under the Creative Commons Attribution License, which permits unrestricted use, distribution, and reproduction in any medium, provided the original work is properly cited. (2019 by author. 


\section{Koresponden:}

Vera Wahyuni,

Email: Verawahyuni666@gmail.com

\section{PENDAHULUAN}

Pendahuluan sedikit berbeda dari abstrak yang singkat dan ringkas. Pembaca perlu mengetahui latar Pendidikan bagi umat manusia merupakan kebutuhan mutlak yang harus dipenuhi sepanjang hayat, tanpa pendidikan sama sekali mustahil satu kelompok manusia dapat hidup berkembang sejalan dengan aspirasi untuk maju sejahtera dan bahagia menurut konsep pandangan hidup mereka. Undang-Undang Sisdiknas No 20 tahun 2003 bab 1 pasal 1 ayat 1 menyatakan bahwa:

"Pendidikan adalah usaha sadar dan terencana untuk mewujudkan suasana belajar dan proses pembelajaran agar peserta didik secara aktif mengembangkan potensi diri, kepribadian, kecerdasan, akhlak mulia, serta keterampilan yang diperlukan dirinya, masyarakat, bangsa dan negara." 1

Saat ini yang menunjukan keberhasilan suatu pendidikan adalah hasil ujian nasional, peserta didik yang lulus pada ujian nasional dinyatakan berhasil dalam proses pendidikan sebaliknya apabila peserta didik tidak lulus dalam ujian nasional dinyatakan belum berhasil dalam proses pendidikan. Salah satu mata pelajaran yang termasuk dalam ujian nasional adalah matematika.

Matematika sebagai salah satu ilmu dasar baik aspek teori maupun aspek terapanya mempunyai peranan yang sangat penting dalam upaya meningkatkan penguasaan sains dan teknologi tersebut. Matematika merupakan bagian dari tolak ukur kemajuan ilmu pengetahuan dan teknologi. Kenyataannya matematika diangggap sebagai mata pelajaran yang sulit dan membingungkan bahkan menakutkan bagi sebagian besar peserta didik.

Kebanyakan guru matematika hanya menekankan pada materi semata dan lebih banyak menjalin komunikasi satu arah dengan peserta didik (teacher center) sehingga peserta didik kurang aktif dalam menyampaikan ide-idenya. Penumpukan informasi dari guru tersebut menjadikan gaya belajar peserta didik yang cenderung menghafal. Selain itu, banyak guru matematika lebih mengutamakan hasil peserta didik dibandingkan melihat proses yang diakukan peserta didik untuk memperoleh hasil tersebut. Proses penyampaian ide-ide dalam suatu permasalahan, penggunaan simbol-simbol untuk menyelesaikan masalah itu terabaikan dan tidak terlihat jika hasil yang didapat tidak sesuai jawaban.

Komunikasi matematis diperlukan dalam pembelajaran matematis karena komunikasi yang benar akan menjadikan proses pembelajaran berjalan dengan lancar. Komunikasi dengan menggunakan simbol, tabel, dan diagram akan sangat penting serta sangat membantu mempermudah peserta didik dalam memahami pelajaran yang mereka terima.

Komunikasi matematis termasuk dalam tujuan pembelajaran matematika dan menjadi bagian standar kompetensi lulusan peserta didik sekolah dari pendidikan dasar hingga sekolah menengah sebagai mana Peraturan Menteri 22 tahun 2006 tentang Standar Kompetensi Kelulusan dalam bidang matematika yang secara lengkap disajikan sebagai berikut:

1. Memahami konsep matematika, menjelaskan keterkaitan antar konsep dan mengaplikasikan konsep atau algoritma luwes, akurat, efisien dan tepat dalam pemecahan masalah.

2. Menggunakan penalaran pada pola dan sifat melakukan manipulasi matematika dalam membuat generalisasi, menyusun bukti, atau menjelaskan gagasan dan pernyataan matematika.

3. Memecahkan masalah yang meliputi kemampuan memahami masalah merancang model matematika, menyelesaikan model, menafsirkan solusi yang diperoleh.

4. Mengkomunikasikan gagasan dengan simbol, tabel, diagram, atau media lain.

5. Memiliki sikap menghargai kegunaan matematika dalam kehidupan yaitu memilik rasa ingin tahu, perhatian, ada minat dalam mempelajari matematika, serta sikap ulet dan percaya diri dalam pemecahan masalah. ${ }^{2}$

\footnotetext{
${ }^{1}$ Undang-undang SISDIKNAS(UU RI No.20 Th,2003),( jakarta: sinar grafika,2013)

${ }^{2}$ Ibid.h. 3
} 
Berdasarkan tujuan pembelajaran matematika di atas, maka untuk membantu peserta didik dalam memahami serta menguasai matematika, perlu usaha yang maksimal agar tujuan pembelajaran dapat tercapai sesuai dengan yang diharapkan. Salah satu yang dapat dilakukan dalam hal ini adalah guru harus dapat memilih model pembelajaran matematika yang tepat sehingga peserta didik dapat memahami konsep matematika dengan baik, mampu mengembangkan kemampuan menyampaikan informasi atau mengkomunikasikan gagasan serta mampu menuangkannya dalam bentuk matematis dari konsep matematika tersebut.

Kemampuan komunikasi matematis perlu dikembangkan agar peserta didik dapat menyelesaikan berbagai permasalahan yang dihadapi dalam pembelajaran matematika serta dapat menyampaikan ideidenya secara langsung baik secara tertulis maupun lisan.

Berdasarkan observasi yang dilakukan di kelas VIII SMP PGRI 1 Batanghari, guru di sekolah tersebut masih menggunakan metode ceramah. Tampak bahwa pembelajaran masih berpusat pada guru dan peserta didik pasif sebab guru memegang peranan yang lebih dominan. Guru hanya menguraikan materi kemudian memberikan tugas sedangkan peserta didik hanya mendengarkan penjelasan guu sehingga peserta didik cepat mengantuk dan merasa bosan karena konsentrasi peserta didik akan mengalami penurunan setelah mendengarkan ceramah 20 menit secara terus menerus selebihnya konsentrasi peserta didik terbagi dan mulai membuat dunia sendiri sehingga apa yang disampaikan oleh guru tidak dapat diterima dengan baik, peserta didik tidak memahami materi/konsep yang dijelaskan. Dengan demikian, peserta didik tidak dapat menyampaikan ide-ide/gagasan dan mengkonstruksi pengetahuanya sendiri.

Hal ini di dukung oleh pendapat E.J.Thomas, 1970 dalam Budiardjo,L Menurut E.J.Thomas Hasil penelitian menunjukkan bahwa konsentrasi peserta didik akan menurun dengan cepat setelah ia mendengarkan ceramah lebih dari 20 menit secara terus menerus. ${ }^{3}$

Hasil wawancara dengan guru mata pelajaran matematika kelas VIII SMP PGRI 1 Batanghari, diperoleh keterangan bahwa pada dasarnya sebagian besar peserta didik mempunyai kemapuan yang cukup dalam matematika. Namun, kemampuan komunikasi matematika masih tergolong rendah. Menurut guru tersebut , masih rendahnya kemampuan komunikasi matematika peserta didik dapat dilihat dari :

1. Peserta didik kurang paham terhadap suatu konsep matematika .

2. Peserta didik belum mampu menyebutkan rumus matematika dengan tepat..

3. Ketika dihadapkan dengan soal cerita, peserta didik tidak terbiasa menuliskan apa yang diketahui dan apa yang ditanyakan dari soal sebelum menyelesaikanya sehingga sering kali peserta didik salah menyimpulkan maksud dari soal cerita tersebut.

4. Masih adanya rasa malu dan enggan untuk sesekali mengungkapkan atau mengkomunikasikan gagasan-gagasan melalui simbol, gambar, tabel, grafik, maupun diagram.

Masalah tersebut menggambarkan bahwa peserta didik masih rendah dalam memahami ide-ide matematis baik secara lisan maupun tulisan sehingga berdampak pada hasil belajar mereka yang juga rendah. Berikut tabel hasil belajar matematika peserta didik.

Tabel 1

Nilai Semester Ganjil Kelas VII SMP PGRI Batanghari

\begin{tabular}{|c|c|c|c|c|c|c|}
\hline \multirow[t]{2}{*}{ NO } & \multirow[t]{2}{*}{ Kelas } & \multicolumn{4}{|c|}{ Prestasi } & Jumlah \\
\hline & & $\geq 85$ & $80>x \geq 70$ & $70>x \geq 55$ & $<55$ & \\
\hline 1 & VIII.1 & 7 & 4 & 9 & 10 & 30 \\
\hline 2 & VIII. 2 & 6 & 5 & 8 & 11 & 30 \\
\hline 3 & VIII.3 & 7 & 7 & 6 & 10 & 30 \\
\hline 4 & VIII.4 & 5 & 4 & 9 & 12 & 30 \\
\hline 5 & VIII.5 & 5 & 4 & 10 & 11 & 30 \\
\hline \multicolumn{2}{|c|}{ Jumlah } & 30 & 24 & 42 & 54 & 150 \\
\hline
\end{tabular}

Sumber : guru matematika kelas VII dan daftar nilai semester genap peserta didik kelas VII tahun 2021

Data yang diperoleh dari hasil semester genap atau nilai kenaikan kelas di atas dapat diketahui 96 dari 150 peserta didik mendapat nilai di bawah Kriteria Ketuntasan (KKM) yakni 70, Jika dihitung dalam persen 64\%. Hal ini merupakan indikasi bahwa hasil belajar matematika peserta didik kelas VIII SMP PGRI 1

\footnotetext{
${ }^{3}$ Tukiran Taniredja. Efi Miftah Faridli. Sri Harmianto. Model-Model Pembelajaran Inovatif dan Efektif. (Bandung:Alfabeta)
} 
Batanghari belum memuaskan. Kondisi ini disebabkan karena dalam pembelajaran matematika peserta didik jarang sekali diminta untuk merefleksikan gambar, grafik ke dalam ide-ide matematika, menyatakan suatu peristiwa sehari-hari dalam bahasa atau simbol matematika, memberikan penjelasan ide suatu konsep atau situasi matematika dengan bahasa sendiri dalam bentuk penulisan matematis. Kemudian tidak hanya itu peserta didik bahkan jarang membuat konjektur mengurus argumen, merumuskan definisi dan argumentasi atau bahkan sekedar menjelaskan dan membuat pertanyaan matematika yang telah dipelajari, mendengarkan dan berdiskusi dengan peserta didik lainnya kemudian membaca dengan pemahaman matematika tertulis.

Permasalahan yang menyebabkan hasil belajar peserta didik yang masih rendah ternyata setelah penulis melakukan pra survey hal tersebut disebabkan oleh peserta didik yang belum mampu memahami maksud suatu soal berbentuk cerita kemudian menuangkannya dalam bentuk matematika serta komunikasi antar peserta didik dengan peserta didik yang lain maupun antar peserta didik dengan guru masih kurang, sehingga mengakibatkan keaktifan dan partisipasi peserta didik dalam mengikuti pelajaran masih kurang. Peserta didik cenderung menerima apa yang telah guru sampaikan akan tetapi tidak dapat mengungkapkannya dalam bentuk matematika. Selain dari kemampuan komunikasi matematis yang masih rendah, penggunaan model pembelajaran yang cenderung monoton dan kurang bervariasi sehingga dalam pembelajaran peserta didik kurang berpartisipasi karena masih berpusat pada guru.

Mengingat bahwa pentingnya kemampuan komunikasi matematis maka perlu dikembangkan model pembelajaran yang erat hubunganya dengan kemampuan komunikasi matematis. Model tersebut diantaranya adalah model pembelajaran tipe Talking Chips. Model pembelajaran tipe Talking Chips yaitu setiap anggota mendapat Chips yang berbeda yang digunakan setiap kali mereka ingin berbicara mengenai menyatakan keraguan, bertanya, menjawab pertanyaan, mengungkapkan ide, mengklasifikasi pertanyaan, memberikan penghargaan untuk ide yang dikemukakan anggota lain dengan mengatakan hal yang positif. Model pembelajaran tipe Talking Chips menuntut bahwa setiap peserta didik mendapat kesempatan yang sama mengemukakan pendapat secara lisan, menjawab pertanyaan serta menjelaskanya, terbentuk dalam kelompok-kelompok kecil yang terdiri dari 4-5 anggota yang masing-masing anggotanya mendapatkan Chips dan memiliki kesempatan yang sama berbicara sebanyak Chips tersebut apabila Chips pada semua anggota sudah habis dan diskusi belum selesai Chips boleh dibagikan kembali. Model pembelajaran Talking chips dinilai dapat meningkatkan kemampuan komunikasi matematis karena dalam model pembelajaran tersebut terlihat bahwa peserta didik dituntut aktif berkomunikasi menyampaikan gagasan ataupun rasa ingin tahu mereka, mengkomunikasikan ke dalam bentuk matematika serta setiap peserta didik memiliki kesempatan yang sama untuk berkomunikasi dan menyampaikan ide.

Model Kancing gemerincing pertama kali dikembangkan oleh spencel kagan pada tahun 1992. Model pembelajaran kooperatif tipe Talking Chips (kancing gemerincing) adalah jenis metode struktural yang mengembangkan adanya hubungan timbal balik antar anggota kelompok didasari adanya kepentingan yang sama. Kagan mengungkapkan tipe kancing gemerincing dengan istilah Talking Chips. Chips yang dimaksud oleh kagan dapat berupa benda berwarna yang ukuranya kecil.

Menurut Djaramah dalam kegiatan Talking Chips (kancing gemerincing), masing-masing anggota kelompok mendapatkan kesempatan untuk memberikan kontribusi, mendengarkan pendapat dan pemikiran anggota yang lain. Model Talking Chips ini memastikan bahwa peserta didik mendapat kesempatan untuk berperan serta dan berkontribusi pada kelompoknya masing-masing. ${ }^{4}$

Keunggulan Talking Chips (Kancing gemerincing) dapat diterapkan semua mata pelajaran dan tingkatan kelas. Dalam kegiatan Talking Chips (kancing gemerincing), masing-masing anggota kelompok berkesempatan memberikan kontribusi mereka dan mendengarkan pandangan anggota lain. Dapat digunakan untuk mengatasi hambatan pemerataan kesempatan yang sering mewarnai kerja kelompok. Dalam kebanyakan kelompok, sering kali ada satu anak/anggota yng terlalu dominan dan banyak bicara. Sebaliknya ada yang pasif dan pasrah saja pada rekanya yang lebih dominan. Dalam situasi seperti ini, pemerataan tanggung jawab dalam kelompok bisa jadi tidak tercapai karena anak yang pasif terlalu menggantungkan diri pada rekannya yang dominan. Teknik ini memastikan setiap peserta didik mendapat kesempatan yang sama untuk berperan serta dan berkontribusi pada kelompoknya masing-masing. ${ }^{5}$

\footnotetext{
${ }^{4}$ Agustin Nurhidayah. 2013.Efektivitas Model Pembelajran Kancing Gemerincing (talking chips) dan Bertukar Pasangan Berbantu CD Pembelajaran pada Hasil Belajar Peserta Didik SMP,

${ }^{5}$ Miftahul Huda. Cooperative Learning.(Yogyakarta: Pustaka Pelajar, 2012)
} 
Sedangkan kelemahan dari kancing gemerincing (Talking Chips) adalah membutuhkan waktu yang lama dan kadang-kadang peserta didik dapat terjebak dengan orang yang harus melakukan semua pekerjaan dan tidak membantu sehingga dia bekerja sendiri. ${ }^{6}$

Adapun prosedur dalam pembelajaran koopertif tipe kancing gemerincing (Talking Chips) menurut Huda

1. Guru menyiapkan satu kotak kecil yang berisi kancing-kancing (atau benda benda kecil lainya).

2. Sebelum memulai tugasnya, masing-masing anggota dari setiap kelompok mendapatkan 2 atau 3 buah kancing (jumlah kancing bergantung pada sukar tidaknya tugas yang diberikan)

3. Setiap kali anggota selesai berbicara atau mengeluarkan pendapat, dia harus menyerahkan salah satu kancingnya dan meletakannya di tengah-tengah meja kelompok.

4. Jika kancing yang dimiliki salah seorang habis, dia tidak boleh berbicara lagi sampai semua rekanya menghabiskan kancing masing-masing.

5. Jika semua kancing sudah habis, sedangkan tugas belum selesai, kelompok boleh mengambil kesepakatan untuk membagi-bagi kancing lagi dan mengulangi prosedurnya kembali. ${ }^{7}$

Prosedur penerapan pembelajaran dengan model pembelajaran tipe Talking Chips (kancing gemering) yang dilaksanakan dalam penelitian ini berpedoman pada pendapat di atas, secara keseluruhan dalam pelaksanaanya guru melewati tiga tahap pembelajaran, yaitu kegiatan awal, tahap kegiatan inti, dan tahap kegiatan akhir. Secara lebih rinci akan diuraikan berikut.

Pertama, tahap kegiatan awal:

1) Melaksanakan kegiatan rutin: salam, berdoa dan mengabsen peserta didik

2) Melaksanakan apersepsi dengan memberikan berbagai pertanyaan atau pengerahan perhatian untuk menuju pada materi yang akan diberikan

3) Menginformasikan pokok bahasan/materi yang akan disampaikan

4) Menjelaskan prosedur-prosedur yang akan dilaksanakan

5) Membentuk kelompok diskusi dengan cara membagu peserta didik ke dalam kelompok, masingmasing kelompok terdiri dari 5-6 peserta didik.

Kedua, tahap kegiatan inti:

1) Peserta didik mengerjakan tugas yang diberikan guru dengan cara berdiskusi dalam kelompok

2) Setelah tugas selesai dikerjakan sesuai dengan waktu yang ditentukan guru, seluruh kelompok melakukan diskusi kelas yang dipimpin oleh guru.

3) Dalam diskusi kelas, guru mengajukan beberapa pertanyaan atau mengemukakan beberapa persoalan yang harus dijawab dan ditanggapi seluruh peserta didik.

4) Setiap kali seorang peserta didik berbicara dan menjawab atau mengeluarkan pendapat dengan benar, peaserta didik harus menyerahkan salah satu kancingnya dan meletakanya di tengah-tengah.

5) Jika kancing yang dimiliki seorang peserta didik habis, peserta didik tidak boleh berbicara lagi sampai semua rekanya juga menghabiskan kancing mereka.

6) Jika semua kancing sudah habis, sedangkan tugas belum selesai, kelompok boleh mengambil kesepakatatan untuk membagi kancing lagi dan mengulangi prosedurnya kembali

Ketiga, tahap kegiatan akhir:

1) Mengadakan evaluasi dengan review materi pembelajaran yang telah disampaikan .

2) Melaksanakan kegiatan rutin: salam, berdoa untuk pulang. ${ }^{8}$

Komunikasi matematis menurut greenes dan schulman (1996) yang menyatakan bahwa komunikasi matematis merupakan (1) kekuatan sentral bagi peserta didik dalam merumuskan konsep dan strategi matematik, (2) modal keberhasilan bagi peserta didik terhadap pendekatan dan penyelesaian dalam

${ }^{6}$ Ika Seftri Ngasaroh.2013. Pengaruh Metode Pembelajaran Kancing Gemerincing Berbantu LKPD pada Sub Pokok Bahasan Mata terhadap Hasil Belajar Peserta Didik Kelas VIII MTs NEGRI 2 RAKIT.

${ }^{7}$ Miftahul Huda Op.Cit 142

${ }^{8}$ Eka Sefri Ngasaroh .Op.Cit h. 15 
ekplorasi dan investigasi matematik, (3) wadah bagi peserta didik dalam berkomunikasi dengan temanya untuk memperoleh informasi, membagi fikiran dan penemuan, curah pendapat, menilai dan mempertajam ide untuk meyakinkan orang lain. ${ }^{9}$

Indikator kemampuan komunikasi matematis merupakan suatu acuan kompetensi komunikasi matematis dapat tercapai atau tidak. Indikator- indikator untuk mengukur kemampuan komunikasi matematis yang diutarakan oleh beberapa pakar diantaranya yaitu Sumarmo, Ross dan NCTM.

Sumarmo mengungkapkan indikator-indikator komunikasi matematika yaitu:

1. Menghubungkan, gambar dan diagram kedalam idea matematika

2. Menjelaskan idea, situasi dan relasi matematika, secara lisan/tulisan dengan benda nyata, grafik dan diagram.

3. Menyatakan peristiwa sehari-hari dalam bahasa atau simbol matematika.

4. Mendengarkan, berdiskusi, dan menulis tentang matematika.

5. Membaca dengan pemahaman suatu prosentasi matematika tertulis.

6. Membuat konjektur, mengurus argumen, merumuskan definisi dan argumentasi.

7. Menjelaskan dan membuat pertanyaan matematika yang telah dipelajari. ${ }^{10}$

\section{METODE}

Metode yang digunakan pada penelitian ini adalah metode kuantitatif diskriptif karena data yang terkumpul berupa angka-angka yang didapat dari hasil pemberian tes obyektif dan diberi nilai tiap-tiap responden. Metode penelitian kuantitatif sudah cukup lama di gunakan sehingga sudah mentradisi sebagai metode untuk penelitian. Metode ini sebagai metode ilmiah (scientific) karena telah memenuhi kaidahkaidah ilmiah ilmiah yaitu kongkrit/empiris, obyektif, terukur, rasional, dan sistematis. Metode ini disebut metode kuantitatif karena data penelitian berupa angka-angka dan analisis data menggunakan statistik dengan permasalahan yang tekah diajukan, sebagaimana yang dikemukakan oleh Sugiyono, yaitu;

Metode penelitian kuantitatif dapat diartikan sebagai metode penelitian yang berlandaskan pada filsafat positivism, digunakan untuk meneliti pada populasi atau sempel tertentu, teknik pengambilan sempel pada umumnya dilakukan secara random, pengumpulan data menggunkan intrumen penelitian, analisis data bersifat kuantitatif/statistic dengan tujuan untuk menguji hipotesis yang telah diterapkan. ${ }^{11}$

Populasi dalam penelitian ini adalah seluruh siswa kelas VIII SMP PGRI Batanghari sebanyak 150 peserta didik, terdistribusi dalam 5 kelas. Sampel pada penelitian ini adalah adalah 2 kelas yang di ambil secara acak dimana satu sebagai kelas kontrol dan satu kelas ekperiment.

\section{HASIL DAN PEMBAHASAN}

Untuk mengetahui validitas alat ukur, penulis melakukan uji coba tes matematika pada materi relasi dan fungsi yang terdiri dari 15 butir soal uraian pada populasi di luar sampel penelitian. Uji coba tes dilakukan pada 30 orang peserta didik kelas kelas IX SMP PGRI 1 Batanghari. Data hasil coba tes dapat dilihat pada tabel 5. Dari hasil perhitungan uji intrumen tes kemampuan komunikasi matematis dengan 15 soal uraian dengan nilai $\alpha=0,05$ dan $r_{\text {tabel }}=0,361$, diperoleh 11 soal yang valid dan 4 soal yang tidak valid yaitu soal no 1,3,12,13 untuk lebih jelas perhitungan validitas dapat di lihat pada

Butir soal yang telah di ujikan sebanyak 15 soal uraian selanjutnya di uji daya pembedanya. Adapun hasil analisis beda butir soal dapat di lihat pada tabel 6. Berdasarkan hasil perhitungan daya pembeda butir soal, diperoleh 2 soal kriteria kurang baik, 1 soal berkriteria baik dan 12 soal berkeriteria sangat baik,untuk lebih jelasnya dapat dilihat pada

Setelah Dilakukan Perhitungan Validitas, Daya Pembeda Butir Soal Serta Tingkat Kesukaran Butir Soal, Diperoleh Rekapitulasi Hasil Analisis Butir Soal Dapat Dilihat Pada Tabel 1

Tabel. 1 Rekapitulasi Hasil

\footnotetext{
${ }^{9}$ Wahid Umar.2012. Membangun Kemampuan Komunikasi Matematis dalam Pembelajaran Matematika, jurnal ilmiah program study matematika STKIP siliwangi bandung

${ }^{10}$ Latifah , Pengaruh Model Pembelajran Kooperatif Tipe Match Mine Terhadap Kemampuan Komunikasi Matemtik Peserta Didik

${ }^{11}$ Sugiyono , Metode Penelitian Pendidikan Pendekatan Kuantitatif, Kualitatif dan R\&D,(Bandung: Alfabeta,2019)
} 
Uji Validitas,Taraf Kesukaran dan Daya Pembeda

\begin{tabular}{|c|c|c|c|c|}
\hline Butir & Validitas & $\begin{array}{c}\text { Tingkat } \\
\text { kesukaran }\end{array}$ & $\begin{array}{c}\text { Daya } \\
\text { pembeda }\end{array}$ & Kesimpulan \\
\hline 1 & tidak valid & Sedang & sangat baik & Tidak digunakan \\
\hline 2 & valid & Sedang & sangat baik & digunakan \\
\hline 3 & tidak valid & Sukar & kurang & Tidak digunakan \\
\hline 4 & valid & Sedang & kurang & Tidak digunakan \\
\hline 5 & valid & Sedang & sangat baik & Digunakan \\
\hline 6 & valid & Sedang & sangat baik & Digunakan \\
\hline 7 & valid & Sedang & sangat baik & Digunakan \\
\hline 8 & valid & Sedang & sangat baik & Digunakan \\
\hline 9 & valid & Sedang & sangat baik & Digunakan \\
\hline 10 & valid & Sedang & sangat baik & Digunakan \\
\hline 11 & valid & Sedang & sangat baik & Digunakan \\
\hline 12 & tidak valid & Sedang & baik & Tidak Digunakan \\
\hline 13 & tidak valid & Sukar & sangat baik & Tidak Digunakan \\
\hline 14 & valid & Sedang & sangat baik & Digunakan \\
\hline 15 & valid & Sedang & sangat baik & Digunakan \\
\hline
\end{tabular}

Berdasarkan tabel diperoleh soal yang valid 11 akan tetapi instrumen yang dipergunakan hanya 10 soal. Soal no 4 tidak dipergunakan meskipun soal tergolong sedang akan tetapi kemampuan soal untuk membedakan antara peserta didik yang berkemampuan tinggi dan berkemampuan rendah kurang.

Perhitungan indeks reliabilitas tes dilakukan terhadap butir tes yang terdiri dari 15 butir yang akan digunakan untuk mengambil data. Pada bab III dikelaskan bahwa suatu tes dikatakan reliabel jika $r_{\text {hitung }}>$ $r_{\text {tabel }}$ dimana koefisien $r_{\text {tabel }}$ adalah 0,361. Dari pembahasan diatas dapat disimpulkan bahwa dari uji coba tes diperoleh tes yang terdiri dari 10 butir yang memenuhi kriteria tes yang diharapkan. Dengan demikian, tes kemampuan kemampuan komunikasi matematis yang digunakan untuk mengambil data telah memenuhi dengan indeks reliabilitas 0,98 memiliki tingkat kesukaran butir antara 0,3 s.d 0,567 dan memiliki daya beda butir soal antara 0,47 s.d 1,47.

Pengambilan data dilakukan setelah proses pembelajaran pada materi bangun relasi dan fungsi. Perangkat pembelajaran dapat dilihat pada tabel 2. Setelah data dari setiap variabel terkumpul selanjutnya digunakan untuk menguji hipotesis. Data tentang kemampuan komunikasi matematis peserta didik pada materi relasi dan fungsi yang sudah diperoleh, selanjutnya dapat dicari nilai tertinggi $\left(\mathrm{X}_{\text {maks }}\right)$ dan nilai terendah $\left(\mathrm{X}_{\min }\right)$ pada kelas kontrol maupun kelas eksperimen. Kemudian dicari ukuran tendensi sentralnya yang meliputi rataan ( $\overline{\mathrm{X}}$ ), median (Me), modus (Mo), dan ukuran variasi kelompok meliputi jangkauan (R) dan simpangan baku (S) yang dirangkum dalam Tabel 4.9. Berdasarkan hasil tes yang diberikan kepada kelas eksperimen dengan model pembelajaran kooperatif tipe Talking Chips sedangkan kelas kontrol dengan model pembelajaran ko nvensional dengan jumlah peserta didik sebanyak 30 peserta didik disajikan pada tabel 2 
Tabel 2

Rekapitulasi Skor Tes Kemampuan Komunikasi Matematis Peserta didik Kelas Eksperimen dan Kontrol

\begin{tabular}{|c|c|c|c|c|c|c|c|c|c|}
\hline Kelas & $\mathbf{N}$ & $\mathbf{X}_{\text {maks }}$ & $\mathbf{X}_{\text {min }}$ & \multicolumn{2}{|c|}{ Ukuran Tendensi Sentral } & \multicolumn{3}{|c|}{$\begin{array}{c}\text { Ukuran Variasi } \\
\text { Kelompok }\end{array}$} \\
\cline { 5 - 10 } & & & & $\overline{\mathbf{X}}$ & $\mathbf{M}_{\mathbf{0}}$ & $\mathbf{M}_{\mathbf{e}}$ & $\mathbf{R}$ & $\mathbf{S}$ & $\mathbf{S}^{\mathbf{2}}$ \\
\hline $\begin{array}{c}\text { Talking Chips } \\
\text { (Eksperimen ) }\end{array}$ & 30 & 100 & 64 & 85,55 & 100 & 86,75 & 34 & 10,58 & $\begin{array}{c}111,9 \\
7\end{array}$ \\
\hline $\begin{array}{c}\text { Konvensional } \\
\text { (Kontrol) }\end{array}$ & 30 & 80 & 30 & 50,05 & $\begin{array}{c}30,40, \\
60\end{array}$ & 47,75 & 50 & 14.47 & $\begin{array}{c}209,3 \\
2\end{array}$ \\
\hline
\end{tabular}

Berdasarkan Tabel 2 ukuran tendensi sentral untuk kelas eksperimen $(t)$ diperoleh nilai Rata-rata $(\overline{\mathrm{X}})$ $=85,55$, median $(\mathrm{Me})=86,75$ modus $(\mathrm{Mo})=100$, untuk nilai ukuran variasi kelompoknya yaitu Varians $\left(S^{2}\right)=111,97$, simpangan baku $(S)=10,58$ dan Jangkauan $(R)=34$.

Berdasarkan Tabel 2 ukuran tendensi sentral untuk kelas kontrol (Konvensional) dimana diperoleh nilai Rata-rata $(\bar{X})=50,05$, median $(\mathrm{Me})=47,75$ modus $(\mathrm{Mo})=30,40$ dan 60 , untuk nilai ukuran variasi kelompoknya, yaitu Varians $\left(\mathrm{S}^{2}\right)=209,32$ simpangan baku $(\mathrm{S})=14.47$ dan Jangkauan $(\mathrm{R})=50$. Berdasarkan hasil tes kemampuan komunikasi matematis pada kelas eksperimen diperoleh nilai terendah 64 dan nilai tertinggi 100 dan untuk kelas kontrol nilai terendah 30 dan nilai tertinggi 100.

Berdasarkan Tabel 2 dan selisih nilai yang telah diuraikan baik dilihat dari ukuran tendensi sentral maupun ukuran dispersi, maka dapat disimpulkan bahwa hasil analisis deskriptif memberikan gambaran kemampuan komunikasi matematis peserta didik berbeda pada setiap kelas. Hal ini juga ditunjukkan dari rata-rata kemampuan komunikasi matematis peserta didik pada kelas kontrol lebih rendah dari pada kelas eksperimen dengan rata-rata kemampuan komunikasi matematis peserta didik pada kelas eksperimen lebih tinggi dari kelas kontrol. Akan tetapi, untuk mengetahui perbedaan tersebut signifikan atau tidak, maka dilakukan uji statistik dengan asumsi.

Perhitungan analisis data yang telah dilakukan $\boldsymbol{F}_{\text {observasi }}=\mathbf{7 8 . 2 6 1}$ dan $\boldsymbol{F}_{\text {tabel }}(0.05,2,87)=3,101$ berdasarkan perhitungan di atas terlihat bahwa $\boldsymbol{F}_{\text {observasi }}>\boldsymbol{F}_{\text {tabel }}$ maka $H_{0}$ ditolak. Hal ini menunjukan bahwa model pembelajaran tersebut memiliki pengaruh atau efek yang tidak sama terhadap kemampuan komunikasi matematis peserta didik kelas VIII SMP PGRI 1 Batanghari dalam pokok bahasan relasi dan fungsi.

Setelah keputusan uji ANAVA, $H_{0}$ ditolak maka untuk melihat perbedaan pengaruh yang paling baik atau untuk menentukan penerapan model pemberajaran manakan yang paling baik, dilakukan uji komparansi ganda (uji lanjut dengan metode Scheffe'. Perhitungan uji komparansi ganda yang telah dilakuka diperoleh $F_{1-3}=1.201$ dan DK $\{\mathrm{F} \mid \mathrm{F}>(2)(3,101)\}=\{\mathrm{F} \mid \mathrm{F}>6,202\}$. Hasil rekapitulasi uji komparansi ganda dengan metode Scheffe' dapat dilihat pada tabel 3.

Tabel .3

\section{Rangkuman Uji Komparasi Ganda Metode Scheffe'}

\begin{tabular}{|l|l|l|l|}
\hline \multicolumn{1}{|c|}{ Komparasi } & F $_{\text {hitung }}$ & \multicolumn{1}{|c|}{$\mathbf{F}_{\text {tabel }}$} & \multicolumn{1}{c|}{ Keputusan Uji } \\
\hline$\mu_{1}$ vs $\mu_{2}$ & 1.201 & 6,202 & $\mathrm{H}_{0}$ ditolak \\
\hline
\end{tabular}

Keterangan :

$\mu_{1}$ : rata-rata kemampuan komunikasi matematis peserta didik kelas kontrol

$\mu_{2}$ : rata-rata kemampuan komunikasi matematis peserta didik kelas eksperimen 
dengan membandingkan $\mathrm{F}_{\text {hitung }}$ dengan $\mathrm{F}_{\text {tabel }}$ bahwa perbedaan yang signifikan terjadi pada komparansi $\mu_{1}$ vs $\mu_{2}$ terlihat perbedaan yang signifikan. Dari rangkuman tabel 3 maka di peroleh:

Kemampuan komunikasi matematis peserta didik yang menggunakan model pembelajaran tipe Talking Chips lebih baik dari pada model pembelajaran konvensional.

\section{Kesimpulan}

Berdasarkan landasan teori, analisis data dan pengujian hipotesis serta mengacu pada perumusan masalah yang telah diuraikan maka dapat disimpulkan bahwa:" Terdapat perbedaan hasil kemampuan komunikasi matematis peserta didik dengan diterapkannya model pembelajaran kooperatif tipe Talking Chips dengan kata lain penerapan model pembelajaran kooperatif tipe Talking Chips Memiliki Pengaruh Yang Signifikan Model Pembelajaran Talking Chip Terhadap Kemampuan Komunikasi Matematis Peserta Didik"

\section{REFERENSI}

Agustin Nurhidayah. 2013.Efektivitas Model Pembelajran Kancing Gemerincing (talking chips) dan Bertukar Pasangan Berbantu CD Pembelajaran pada Hasil Belajar Peserta Didik SMP

Ika Seftri Ngasaroh.2013. Pengaruh Metode Pembelajaran Kancing Gemerincing Berbantu LKPD pada Sub Pokok Bahasan Mata terhadap Hasil Belajar Peserta Didik Kelas VIII MTs NEGRI 2 RAKIT

Miftahul Huda. Cooperative Learning.(Yogyakarta: Pustaka Pelajar, 2012)

Sugiyono, Metode Penelitian Pendidikan Pendekatan Kuantitatif, Kualitatif dan R\&D,(Bandung: Alfabeta,2019)

Tukiran Taniredja. Efi Miftah Faridli. Sri Harmianto. Model-Model Pembelajaran Inovatif dan Efektif. (Bandung:Alfabeta)

Wahid Umar.2012. Membangun Kemampuan Komunikasi Matematis dalam Pembelajaran Matematika, jurnal ilmiah program study matematika STKIP siliwangi bandung

Undang-undang SISDIKNAS(UU RI No.20 Th,2003),( jakarta: sinar grafika,2013) 